\title{
PENGGUNAAN INTERNET UNTUK KEEFEKTIFAN KOMUNIKASI INTERPERSONAL DI KALANGAN MAHASISWA
}

\author{
Deri Rana, Agus Setiaman, Ira Mirawati \\ Universitas Padjajaran
}

\begin{abstract}
ABSTRAK
Penelitian ini bertujuan untuk mengetahui intensitas, valensi, serta bobot informasi untuk keefektifan komunikasi interpersonal di kalangan mahasiswa. Metode yang digunakan adalah metode studi deskriptif yaitu memaparkan dan menganalisis data yang diperoleh. Data primer didapat melalui penyebaran angket dan data sekunder diperoleh melalui studi kepustakaan. Teknik penarikan sampel yang digunakan adalah teknik sampling acak sistematik. Populasi dalam penelitian ini adalah anggota yang terdaftar sebagai pengguna jasa Jihadnet hingga Juni 2012. Jumlah responden adalah sebanyak 61 orang yang diperoleh berdasarkan teknik sampling acak sistematik. Pengolahan data dilakukan dengan menggunakan uji validitas, uji reliabilitas, dan analisis deskriptif. Hasil dari penelitian ini, yaitu penggunaan internet di kalangan mahasiswa member Jihadnet cukup mendukung keterbukaan, empati, dukungan, sikap suportif, serta kesetaraan sebagai indikator keefektifan komunikasi interpersonal responden. Dua dari tiga variabel penggunaan internet, yaitu intensitas dan valensi diapresiasi tinggi oleh responden. Sementara bobot informasi diapresiasi sedang oleh responden
\end{abstract}

Kata-kata Kunci: Korupsi, Kader Demokrat, Kepercayaan

\section{EXPOSURE IMPRESSIONS AT METRO TV NEWS CONCERNING CORRUPTION CASE INVOLVING CADRE FROM DEMOCRAT PARTY IN LEGISLATIVE TOWARD STUDENT'S TRUST FROM FACULTIES OF SOCIAL AND POLITICAL SCIENCE PADJAJARAN UNIVERSITY TO INDONESIAN PRESIDENT}

\section{ABSTRACT}

This study was to determine the intensity, valence, and information weight for the effectiveness of interpersonal communication among students. The method used was descriptive research method to describe and analyze the data obtained. The primary data obtained through questionnaires and secondary data obtained through the study of literature. The sampling technique used was systematic random sampling technique. The population in this study are listed as members of Jihadnet until June 2012. The number of respondents was as many as 61 people, were obtained by systematic random sampling technique. Data processing was done using validity test, reliability test, and descriptive analysis. The conclusions drawn from this study, is that the use of the internet among students, members of Jihadnet, quite supporting to openness, empathy, support, supportive attitude, and equity as an indicator of the effectiveness of respondents' interpersonal communication. Two of the three variables of internet usage, which are the intensity and valence was highly appreciated by respondents. While the information weight was being averagely appreciated by the respondents

Keywords : Corruption, Demokrat Cadre, Trust

Korespondensi: Azka Haria Putri. Universitas Padjadjaran. Jl. Raya Bandung Sumedang KM.21, Hegarmanah, Jatinangor, Kabupaten Sumedang, Jawa Barat 45363 Email:haria.azka@gmail.com 


\section{PENDAHULUAN}

Media massa seketika menjadi sumber konsumsi informasi sehari-hari bagi masyarakat. Berbagai lapisan, berbagai tingkat kasta manusia, menerima berbagai informasi yang disebarkan oleh media massa. Pengertian komunikasi massa sendiri, merujuk pada pendapat Tan dan Wright, merupakan bentuk komunikasi yang menggunakan saluran (media) dalam menghubungkan komunikator dan komunikan secara massal, berjumlah banyak, bertempat tinggal yang jauh (terpencar), sangat heterogen dan menimbulkan efek tertentu (Ardianto, $2004: 3$ ).

Perkembangan media massa saat ini meningkat tajam seiring meningkatnya kebutuhan manusia akan informasi, karena media massa secara langsung mendukung aktifitas masyarakat. Pada hakikatnya media adalah perpanjangan lidah dan tangan yang berjasa meningkatkan kapasitas manusia untuk mengembangkan struktur sosialnya (Rivers, 2001: 27).

Tidak diragukan lagi televisi merupakan aktivitas waktu luang paling popular di dunia. Di seluruh dunia ini akan ada 3,5 milyar jam dihabiskan untuk menonton televisi (Kubeyn \& Csikzentmihalyi).

Menurut data dari Nielsen, "The average household in america has the television turned on for eight hours and 11 minutes a day". Lebih dari sepertiga hari mereka digunakan untuk menonton televisi, walaupun banyak juga dari mereka yang menonton televisi sambil melakukan aktifitas yang lain.
Peran televisi merambah ke berbagai aspek kehidupan. Misalnya dalam bidang pendidikan, ekonomi, budaya, politik dan hiburan. Seperti dengan ditayangkannya program kuis cerdas cermat, pengenalan terhadap kebudayaan Indonesia, sampai kepada program infotainment yang menyajikan informasi tentang dunia selebriti. Semuanya itu telah memudahkan kita untuk menerima pesan dari informasi yang diberikan nara sumber melalui televisi dan disebarkan kepada khalayak, sungguh menakjubkan hanya dengan sekali pandang televisi kita bisa mendapatkan banyak informasi yang global.

Menurut Ibnu Hamad (2004:XV) dalam bukunya Konstruksi realitas politik dalam media massa ada lima aspek yang membuat media massa penyinga dalam kehidupan politik, yaitu:

Pertama, daya jangkaunya yang sangat luas dalam menyebarkan informasi, yang mampu melewati batas wilayah (geografis), kelompok umur, jenis kelamin dan status sosial-ekonomi (demografis) dan perbedaan paham dan orientasi (psikografis). Dengan begitu, suatu masalah politik yang dimediasikan menjadi perhatian bersama di berbagai tempat dan kalangan.

Kedua, kemampuannya dalam melipatgandakan pesan yang luar biasa. Sejumlah berita dapat dilipat-gandakan jumlah eksemplarnya, penayangannya, sehingga berdampak besar terhadap khalayak.

Ketiga, setiap media bisa mewacanakan sebuah peristiwa politik sesuai pandangannya masing-masing. 
Keempat, tentu saja dengan fungsi agenda setting yang dimilikinya, media memiliki kesempatan yang sangat luas untuk menyebarkan berita politik. Belum tentu berita politik yang menjadi agenda media menjadi agenda publik juga.

Kelima, pemberitaan peristiwa politik oleh suatu media lazimnya berkaitan dengan media lainnya hingga membentuk rantai informasi. Hal ini akan menambah kekuatan tersendiri terhadap penyebaran pemberitaan politik dan dampaknya terhadap publik. Maka semakin kuatlah peran media dalam membentuk opini publik.

Sejak tahun 2000 Metro TV telah menyampaikan visi misi sebagai televisi yang menyajikan program berita, hiburan dan gaya hidup yang berkualitas. MetroTV dikenal sebagai The Election Channel Referensi Pemilu Indonesia sejak tahun 2004 dilanjutkan pada tahun 2009 dengan visi untuk mengedukasi masyarakat melalui program-program election dan event pemilu yang merupakan titik awal ketika seluruh masyarakat ikut berperan langsung dalam prosesi politik secara demokrasi ${ }^{1}$. Melalui triangle strategy yaitu positioning-diferensiasi-brand merupakan sebuah 'intisari' strategi yang digunakan oleh Metro TV yang berfungsi sebagai pedoman dalam menjalankan segala aktivitas perusahaan yang menjadi landasan bagi keunggulan kompetitif jangka panjang merupakan sebuah ide yang valid. Triangle Strategy inilah yang membawa masyarakat untuk memaknai dengan jelas program
The Election Channel 2009 dibanding dengan program yang ditawarkan oleh kompetitor.

Semenjak Metro TV mengklaim dirinya sebagai televisi berita dengan mengangkat program The Election Channel maka semenjak itu juga Metro TV secara langsung dan terbuka mengikuti berbagai perkembangan yang terjadi pada pemerintahan SBY. Metro TV sebagai Industri Media berperan sebagai kamera pengintai bagi kinerja pemerintah yang kemudian dipersembahkan melalui media sebagai hasil interpretasi mereka. Namun tidak hanya itu, dari fenomena MetroTV ini kita dapat melihat peran Hegemony media. Metro TV berupaya menanamkan kerangka berpikir tertentu kepada audiens mereka. Kritik menjadi suguhan disetiap acara yang disajikan. Metro TV seperti ingin menanamkan idiologi tertentu kepada khalalyak yang menonton. Pagi hari, ketika kita menonton MetroTV, acara "Editorial Media Indonesia" sudah menanti. Disusul dengan "Eight to Eleven Show". Sore hari kita akan disuguhkan acara Metro Realitas, Metro Hari Ini, sampai pada Suara Anda.

Setelah terpilihnya partai Demokrat sebagai pemenang pilpres 2009 untuk kedua kalinya, Metro TV tetap gencar untuk selalu memberitakan berbagai peristiwa dan kejadian-kejadian yang menyangkut Partai Demokrat. Kasus-kasus yang menimpa Partai demokrat, baik itu masalah kadernya atau konflik internal partai selalu sering menjadi headline diberbagai acara yang disajikan Metro TV. Tentunya masyarakat melihat apa yang

\footnotetext{
${ }^{1}$ Mediaindonesia.com, 24 Mei 2008
} 
terjadi pada Partai Demokrat, apalagi Partai Demokrat adalah partai pemenang pemilu. Semakin gencarnya pemberitaan tentang partai demokrat oleh Metro TV, semakin masyarakat dibentuk untuk berpandangan sesuai cara pandang Metro TV sebagai media yang menyajikan informasi tersebut.

Ramainya pemberitaan mengenai kasus korupsi yang menjerat kader Partai Demokrat yang duduk di Legislatif ini, tentunya dapat menurunkan citra Partai Demokrat dan akibat lebih lanjutnya akan menurunkan elektabilitas Partai Demokrat dalam menghadapi persaingan dengan partai lainnya, sehingga lama-kelamaan membuat Partai Demokrat gerah.

Bahkan Partai Demokrat sempat mengadukan Metro TV ke KPI (Komisi Penyiaran Indonesia) karena merasa bahwa pemberitaan yang ditayangkan oleh Metro TV seputar kasus korupsi yang menimpa kader mereka terlalu berlebihan dan dipengaruhi oleh kepentingan politik pemiliknya. Seperti kasus yang menimpa Angelina Sondakh, dan Nazzaruddin. Metro TV dianggap mengeneralisasi bahwa semua kader Partai Demokrat terlibat korupsi, sehingga hal ini bisa memperburuk citra Partai Demokrat.

Susilo Bambang Yudhoyono yang merupakan Presiden Republik Indonesia dan juga Ketua Dewan Pembina Partai Demokrat tentunya juga merasa resah terhadap berbagai kasus yang menimpa Partai Demokrat. Secara tidak langsung berbagai kritikan yang ditujukan kepada Partai Demokrat juga merupakan kritikan atas dirinya. Banyak kalangan yang menilai dia telah gagal membersihkan partainya dari korupsi, padahal moto politik yang bersih dan santun selalu digembar-gemborkan ketika awal berdirinya Partai Demokrat ini.

Dampak yang terasa tidak hanya terhadap citra Partai Demokrat, orang-orang pun mulai meragukan kemampuan SBY untuk dapat memberantas korupsi di Indonesia, karena untuk memberantas korupsi di dalam partainya saja tidak bisa, apalagi memberantas korupsi di seluruh wilayah Indonesia. Tanggapan-tanggapan negatif terus bermunculan, kinerja SBY makin disorot, berbagai kritik dan demonstrasi silih berganti datang untuk menuntut janji-janji yang pernah diucapkan oleh SBY pada saat kampanye pemilihan umum. Rakyat semakin kritis, mahasiswa mulai menunjukan tajinya sebagai insan intelektual yang dapat melakukan perubahan, berbagai aksi dilakukan oleh mahasiswa, seperti tuntutan, tudingan, membentuk aksi kesatuan mahasiswa, sampai ke demostrasi yang menjurus ke aksi anarkis.

Dari permasalahan ini kita bisa mencari tahu bagaimana terpaan tayangan berita di Metro TV yang gencar mengenai berbagai kasus korupsi yang melibatkan kader Partai Demokrat yang duduk di lembaga legislatif dengan kepercayaan mahasiswa terhadap Presiden SBY dengan fokus kepada mahasiswa Fakultas Ilmu Sosial dan Ilmu Politik Universitas Padjajaran.

\section{METODE}

Metodologi yang digunakan dalam penelitian ini adalah metode kuantitatif deskriptif. 
Metode kuantitatif deskriptif bertujuan untuk melukiskan secara sistematis fakta atau karakteristik populasi tertentu atau bidang tertentu secara factual dan cermat. Penelitian ini tidak mencari atau menjelaskan hubungan, tidak menguji hipotesis atau membuat prediksi. Mereka menyebut metode deskriptif ini sebagai penelitian survey atau penelitian observasional (Rakhmat, 1999:24-25).

Oleh Azwar dinyatakan sebagai prosedur penelitian yang menekankan pada data data numerical (angka) yang diolah dengan metode statistic (Azwar,2003:5).

Pada dasarya penelitian deskriptif kuantitatif ini bertujuan untuk menggambarkan secara tepat sifat sifat suatu individu, keadaan, gejala atau kelompok terttentu, atau menentukan frekuensi atau penyebaran suatu gejala atau frekuensi adanya hubungan tertentu antara suatu gejala dengan gejala lain dalam masyarakat (koentjaraningrat, 1990:156).

\section{Teknik Pengumpulan Data}

Teknik pengumpulan data yang digunakan dalam penelitian ini adalah (1) kuesioner, yaitu daftar pertanyaan yang telah disusun secara tertulis sesuai dengan operasionalisasi variabel, dan merupakanalat untuk mendapatkan data primer dari penelitian. Peneliti menggunakan kuesioner. Pertanyaan dalam kuesionar ini dengan pertanyaan alternatif jawaban (tertutup); (2) wawancara, yaitu teknik komunikasi yang dilakukan secara langsung untuk memperoleh keterangan secara lisan dengan pihak yang terkait dan mendukung dalam penelitian. Wawancara ini bertujuan untk melengkapi deskripsi untuk hasil penelitian nanti. Wawancara yang dilakukan dengan tanya jawab langsung dengan mahasiswa FISIP (Fakultas Ilmu Sosial dan Ilmu Politik) dengan sifat informal dan tidak berstruktur; (3) studi kepustakaan, diperoleh melalui pengumpulan data teoretis yang berhubungan dengan teori-teori yang berkaitan dengan variabel yang diteliti yaitu bertajuk komunikasi, pemasaran, branding, serta metode penelitian komunikasi.

\section{Teknik Pengambilan Sampel}

Cluster sampling digunakan untuk populasi yang sifatnya dalam bentuk unit-unit khusus seperti agama, golongan, suku, bangsa, atau yang lainnya. Cluster sampling tidak memilih individu-individu sebagai anggota unit sampel, tetapi memilih rumpun-rumpun populasi sebagai anggota unit populasi (Burhan Bungin 2009:113).

Multi Stage Cluster Sampling merupakan salah satu model pengambilan sampel secara acak yang pelaksanaannya dilakukan dengan membagi populasi menjadi beberapa fraksi kemudian diambil sampelnya. Sampel fraksi yang dihasilkan dibagi lagi menjadi fraksi-fraksi yang lebih kecil kemudian diambil sampelnya. Pembagian menjadi fraksi ini dilakukan terus sampai pada unit sampel yang diinginkan.

Multi Stage Random Sampling ini berlangsung dalam tahapan-tahapan sampai kepada fraksi yang paling kecil.

Tahap 1, di Fakultas Ilmu Sosial dan Ilmu Politik Universitas Padjajaran terdapat 7 jurusan 
yaitu: ilmu administrasi negara, ilmu hubungan internasional, ilmu kesejahteraan sosial, ilmu pemerintahan, antropologi, ilmu administrasi bisnis, dan sosiologi. Dari ketujuh jurusan tersebut dilakukan pengundian kembali dengan cara di kocok dan terpilihlah jurusan Ilmu Pemerintahan.

Tahap 2, setelah mendapatkan jurusan Ilmu Pemerintahan, kemudian kita mencari angkatan yang masih aktif diperkuliahan, didapatlah angkatan yang masih aktif diperkuliahan adalah angkatan 2008, 2009, 2010, dan 2011. Dari keempat angkatan tersebut dilakukan pengundian kembali dengan cara dikocok, maka terpilihlah angkatan 2009.

Tahap 3, tahapan terakhir menentukan kelas yang akan dijadikan sampel. Di jurusan Ilmu Pemerintahan ini terdapat dua kelas yaitu kelas A dan kelas B, setelah dilakukan pengundian dengan cara dikocok maka terpilihlah kelas B sebagai sampel penelitian.

Setelah melakukan pengundian dari kluster terbesar sampai ke yang terkecil, maka didapatlah sampel pada penelitian ini adalah mahasiswa Fakultas Ilmu Sosial dan Ilmu Politik Universitas Padjajaran jurusan Ilmu Pemerintahan kelas B angkatan 2009 yang berjumlah 65 orang

Uji validitas pada penelitian ini menggunakan uji statistik Spearmna, skala pengukuran yang digunakan adalah skala ordinal, dengan uji statistik Spearman atau yang disebut juga dengan Rank Order Correlation. Setiap data yang diperoleh, baik variabel $\mathrm{X}$ dan variabel $\mathrm{Y}$ di rangking masing-masing berdasarkan skor masingmasing dari yang terbesar hingga yang terkecil, yaitu 1, 2, 3, ... n (Siegel, 1985:250) dengan rumus sebagai berikut:

a) Skor data rangking

b) Hitung selisih rangking pasangan

c) Selisih pasangan dikuadratkan

d) Jumlahkan hasil penghitungan dari seluruh sampel

e) Hitung $T_{X}$ dan $y_{Y}$ dengan rumus:

$$
T=\frac{t^{\mathrm{a}}-t}{12}
$$

Dengan ketentuan:

$T=$ Besarnya faktor koreksi

$t=$ Jumlah rank kembar dari jumlah variabel yang dimiliki skor sama

f) Masukan data ke dalam rumus Rank Spearman:

$$
r_{s}=1-\frac{6 \sum d i^{2}}{n\left(n^{3-} 1\right)}
$$

; apabila tidak ada nilai pengamatan yang sama

$$
r_{s}=\frac{\sum x^{2}+\sum y^{2}-\sum d i^{2}}{2 \sqrt{\sum x^{2} \cdot \sum y^{2}}}
$$

; apabila ada nilai pengamatan yang sama dimana:

$$
\sum x^{2}=\frac{n^{3}-n}{12}-\sum T x
$$

$\sum \begin{aligned} & y^{2} X_{1}-Y=\frac{n^{3}-n}{Z^{3} \sum T y} \\ & T x, y=\frac{12}{12}\end{aligned}$

Keterangan:

$X=$ Skor item

$Y=$ Skor total

$t=$ jumlah rank yang sama pada

kategori tertentu 


\section{HASIL DAN PEMBAHASAN}

Hasil dari penelitian ini ternyata terpaan tayangan di Metro TV mengenai kasus korupsi kader Partai Demokrat berdampak pada kepercayaan mahasiswa FISIP kepada Presiden RI. Variabel-variabel dari terpaan tayangan sebagian besar berada pada kategori sedang dan tinggi dalam dampaknya terhadap kepercayaan mahasiswa FISIP kepada Presiden RI. Disini bisa kita lihat pengaruh atensi, Focusing Strategic, Involvement, serta Kapasitas ketika menonton berita di televisi menjadi variabel penting dalam pembentukan opini mahasiswa, sehingga ada perubahan-perubahan pandangan yang terjadi, sesuai dengan yang diberitakan di televisi.

Berdasarkan hasil penelitian dan pembahasan tentang terpaan tayangan berita di Metro TV mengenai kasus korupsi yang menjerat kader Partai Demokrat di legislatif terhadap kepercayaan mahasiswa FISIP Unpad kepada Presiden RI, maka dapat diambil simpulan diantaranya sebagai berikut:

Atensi dapat berdampak terhadap kepercayaan seseorang. Dalam penelitian ini, sebagian besar atensi responden terhadap tayangan berita mengenai kader Partai Demokrat yang terjerat kasus korupsi di legislatif berada pada kategori sedang. Dampaknya terhadap kepercayaan kepada presiden dalam kategori sedang juga. Dan tingkat atensi yang tinggi berdampak pada tingkat kepercayaan yang sedang kepada presiden. Atensi disini secara tidak langsung berdampak pada tingkat kepercayaan seseorang pada tokoh yang ditampilkan televisi. Namun, bukan berarti ketika atensi seseorang tinggi terhadap sebuah tayangan, maka dampak dari tayangan tersebut juga tinggi. Ada faktor-faktor lain seperti pengaruh orang dan sumber lain serta cara menonton yang dapat mempengaruhi dampak dari tayangan tersebut.

Sub variabel kedua yaitu kapasitas. Kapasitas juga dapat berdampak terhadap kepercayaan seseorang. Dalam penelitian ini, sebagian besar kapasitas responden terhadap tayangan berita mengenai kader Partai Demokrat yang terjerat kasus korupsi di legislatif berada pada kategori sedang. Dampaknya terhadap kepercayaan kepada presiden dalam kategori sedang juga. Dan tingkat kapasitas yang tinggi berdampak pada tingkat kepercayaan yang sedang kepada presiden, walaupun ada sebagian lagi juga mempunyai tingka kepercayaan yang tinggi kepada presiden. Kapasitas bergantung kepada kebutuhan informasi seseorang. Frekuensi dan durasi seseorang dalam menonton sebuah tayangan televisi tergantung jumlah informasi yang dibutuhkan seseorang. Jika kebutuhan informasi seseorang tinggi, maka kapasitas seseorang dalam menonton tayangan televisi akan cenderung tinggi juga.

Dalam penelitian ini, sebagian besar focusing strategic responden terhadap tayangan berita mengenai kader Partai Demokrat yang terjerat kasus korupsi di legislatif berada pada kategori sedang. Dampaknya terhadap kepercayaan kepada presiden dalam kategori sedang juga. Kegiatan-kegiatan yang kita lakukan ketika menonton televisi akan mempengaruhi keutuhan informasi yang nantinya akan kita pahami. Walaupun dampak dari cara menonton televisi 
terhadap tingkat kepercayaan seseorang tidak begitu terasa, namun faktor ini dapat menjadi penghalang bagi keberhasilan dari dampak televisi.

Involvement (keterlibatan hal lain) juga dapat berdampak terhadap kepercayaan seseorang. Dalam penelitian ini, sebagian besar involvement ketika menonton tayangan berita mengenai kader Partai Demokrat yang terjerat kasus korupsi di legislatif berada pada kategori sedang. Dampaknya terhadap kepercayaan kepada presiden dalam kategori sedang juga. Selain media-media yang ada, orang lain juga bisa jadi penentu dan pembentuk opini kita, sering kali ketika kita sedang menyaksikan televisi bersama keluarga atau teman terjadi interaksi akibat dari informasi yang diberitakan. Dalam keadaan tersebut seseorang biasanya akan memunculkan opini-opini nya sehingga terjadi diskusi kecil diantara orang-orang yang menonton tersebut. Disinilah pengaruh orang lain terhadap pembentukan opini sampai ke kepercayaan seseorang terhadap informasi tersebut muncul, dan ketika mereka merasa tidak cukup puas dengan informasi yang mereka peroleh, bisa jadi mereka mencari informasi-informasi melalui sumber-sumber lainnya.

\section{DAFTAR PUSTAKA}

Ardianto, Elvinaro dan Lukiati Komala Erdinaya. 2004. Komunikasi Massa Suatu Pengantar. PT Remaja Rosdakarya, Bandung.

Ardianto, Elvinaro dkk. 2007. Komunikasi Massa Suatu Pengantar. Bandung: Simbiosa Rekatama Media

Arikunto, S. 1996. Prosedur Penelitian Suatu Pendekatan Praktek. Jakarta: Rineka Cipta
Bakhtiar, Amsal. 2004. Filsafat Ilmu. 2007. Jakarta: Rajagrafindo Persada

Baksin, Askurifai. 2006. Jurnalistik Televisi: Teori dan Praktik. Bandung: Simbiosa Rekatama Media.

Bungin, Burhan. 2005. Metode Penelitian Kuantitatif. Jakarta: Gramedia Pustaka

Jakarta: Kencana.

Effendy, Onong Uchjana. 1992. Ilmu Komunikasi: Teori dan Praktek- cet 6. Bandung: Remaja Rosdakarya.

Hamad, ibnu, 2004. Dr, Konstruksi Realitas Politik dalam Media Massa: sebuah Studi Critical Discourse Analysis terhadap Berita-berita Politik. Jakarta: granit 2004

Hidayat S.E. M.Si., Taufik dan Nina Istiadah, S.T. 2011. Panduan Lengkap Menguasai SPSS 19 Untuk Mengolah Data Statistik Penelitian. Jakarta: PY. TransMedia Jl. Moh. Kahfi II No. 12 A Cipedak, Jagakarsa, Jakarta Selatan

Hofmann, Ruedi, 1999. Dasar-dasar Apresiasi Program Televisi. Jakarta: Grassindo

Kuswandi, Wawan. 1996. Komunikasi Massa Sebuah Analisa Media Televisi. Jakarta: Rhineka Cipta.

Mayer, R.C., Davis, J.H., \& Schoorman, F.D. 1995. "An Integrative $M$ odel of

McQuail. 2000. Mass Communication Theory. London: Sage Publications Inc. 1 Oliver's Road 55 City Road

Moen. R Darly, Don Ranly. 1980. News Reporting and Editing. California: Wadsworth.

Mulyana, Deddy. 2000. Metode Penelitian Komunikasi. PT. Remaja Rosdakarya 
Mulyana, Deddy. 2002. Ilmu Komunikasi Suatu Pengantar. Bandung: PT Remaja Rosdakarya

Newsom, Doug; Wollert, James A. 1985. Media Writing, News for The Mass Media. California: Wadsworth.

Organizational Trust", Academy of Management Review.

Rakhmat, Jalaludin. 2001. Metode Penelitian Komunikasi.Bandung: PT. Remaja Rosdakarya.

Singarimbun dan Effendy. 1987. Metode Penelitian Survei. Yogyakarta : LP3ES

Sternberg, R. J. (2006). Cognitive psychology. (4th ed.). Belmont: Thompson Wodsworth

Sugiyono. 2008. Metode Penelitian Kuantitatif, Kualitatif, dan R\&D. Bandung: CV Alphabeta

Sumadiria, Haris. 2005. Menulis Berita dan Feature (Panduan Praktis Jurnalis Profesional). Bandung: Simbiosa Rekatama Media.

Wahyudi, 1986, Media komunikasi massa televisi, Bandung: Alumni

William L. Rivers, Jay W., Jensen Theodore Peterson, Media Massa Masyarakat Modern, Edisi Kedua, Prenada Media Group, Jakarta Kencana, 2008

Zand, D. (1972), "Trust and Managerial Problem Solving", Administrative Science Quarterly. 